\title{
Proteomics variations after short-term heat shock treatment reveal differentially expressed proteins involved in early microspore embryogenesis in cabbage (Brassica oleracea)
}

\section{Henan Su}

Hunan Agricultural University

\section{Guo Chen}

Hunan agriculture University

Xing Liu

Chinese academy of agriclutural science

Limei Yang

Chinese Academy of agriculture Sciences

\section{Mu Zhuang}

Chinese Academy of agriculture science

\section{Yangyong Zhang}

Chinese Academy of agriculture science

\section{Yong Wang}

Chinese Academy of agriculture science

\section{Zhiyuan Fang}

Chinese Academy of agriculture science

Honghao Lv ( $\sim$ lvhonghao@caas.cn )

Chinese Academy of Agricultural Sciences https://orcid.org/0000-0003-2635-3042

Research article

Keywords: Cabbage, Microspore embryogenesis, Heat shock treatment, Proteomics

Posted Date: July 16th, 2019

DOI: https://doi.org/10.21203/rs.2.11465/v1

License: (c) (1) This work is licensed under a Creative Commons Attribution 4.0 International License. Read Full License 


\section{Abstract}

Background Microspore embryogenesis (ME) provides an efficient way to breed crops. In many cases, short-term heat shock treatment can greatly increase the embryogenesis rate of brassicas. However, its molecular mechanism is largely unclear. Results To mine for the key genes, pathways and interplay in the underlying networks, we compared the proteomes of isolated microspores with samples pre-treated at 32 ${ }^{\circ} \mathrm{C}$ for $24 \mathrm{~h}$ and $25^{\circ} \mathrm{C}$ for $24 \mathrm{~h}$ using two cabbage accessions (Zhonggan 628 and 87-534) showing extremely different embryogenic rates. The embryo yield was 0 and 19.7 embryos/bud for Zhonggan 628 at $25^{\circ} \mathrm{C}$ and $32{ }^{\circ} \mathrm{C}$, respectively, and was 0 for $87-534$ at both temperatures. Using a label-free proteomics technology, more differentially expressed proteins (DEPs) were found for Zhonggan 628 (363 DEPs, 115 upregulated and 248 downregulated) than for 87-534 (282 DEPs, 162 upregulated and 120 downregulated). 97 DEPs specially identified only in Zhonggan 628 but not in 87-534 after heat-shock treatment were the key proteins that maybe related to heat shock-induced embryogenesis in vitro culture. Those 97 DEPs were mainly enriched in carbon metabolic process and protein synthesis and degradation process. Malate dehydrogenase (mMDH), sgt1 homolog B (SGT1), heat shock 70 kDa protein 5 (HSP70), and cell division control protein 48 homolog A (CDC48) may play an important role in cabbage embryogenesis and were identified based on pathway enrichment and protein-protein interaction analyses. In addition, changes in the abundance of 9 representative DEPs were correlated with their corresponding mRNA levels using qRT-PCR. Carbohydrate metabolism supplies the energy needed for the rapid growth that occurs during embryo development, and the folding of synthesized proteins or the refolding of damaged and unstable proteins occur, which may due to the stress induced by in vitro culture. Conclusions A set of putative proteins presumably specific for microspore embryogenesis induced by high temperature treatment were identified. In isolated microspore culture of cabbage, we present the first exposition of non-embryo and the embryo (induced by $32{ }^{\circ} \mathrm{C}$ heat shock treatment $24 \mathrm{~h}$ ) changes in the expression of specific proteins.

\section{Background}

Cabbage (Brassica oleracea L. var. capitata L.) is one of the most cultivated vegetables in the world, the production of cabbage and other brassicas throughout the world was 71.26 million tons in 2016 with China producing 33.88 million tons (http://faostat.fao.org/) [1]. A number of commercial cultivars are F1 hybrids that take advantage of heterosis to ensure uniformity and yield. Thus, we first need to obtain high-generation inbred lines with genetically stable heredity. In the traditional way, inbred line cultivation is laborious and time-consuming, while homozygous breeding materials can be obtained within two years by microspore culture [2]. Microspore culture is an effective alternative technique to produce doubled haploid $(\mathrm{DH})$ parental lines to generate $\mathrm{F}_{1}$ hybrids, the development of $\mathrm{DH}$ lines accelerates the plant breeding process by saving time and labor $[3,4,5,6]$. In addition, the $\mathrm{DH}$ population is an ideal material for genetic analysis, map construction and gene mapping, and the excellent $\mathrm{DH}$ lines obtained after identification also provided a good material basis for cross-breeding [7]. 
Microspore embryogenesis has been described for more than 250 plant species, and efficient protocols are available for Brassica species [8]. In recent years, many researchers have studied and improved isolated microspore culture technology from genotypes, the growth environment of donor plants, microspore development stages, pretreatment conditions, plant regeneration, ploidy identification and chromosome doubling, which has improved the microspore germination rate of some of the genotypes compared to their original state $[9,10]$. Pretreatment is essential to embryo production, microspore and pollen isolated from cruciferous plants can produce haploid embryos in vitro without the need for intermediate callus stage under appropriate stress treatment. The pretreatment is usually carried out under heat treatment of $32-37^{\circ} \mathrm{C}$, lasting from several hours to several days. In $B$. napus, embryogenesis can be induced at least 8 hours after incubation at $32^{\circ} \mathrm{C}$, late unicellular microspores and early bicellular pollen are the best [11]. However, Custers et al. argued that the culture of $B$. napus microspore at $18^{\circ} \mathrm{C}$ is an ideal system for studying the development of rapeseed gametophyte [12]. In cabbage, microspore embryogenesis was significantly enhanced on the heat shock $\left(32.5^{\circ} \mathrm{C}\right)$ for $24 \mathrm{~h}[13,14]$, which is different for broccoli (B. oleracea L. var. italica L.) that the optimum temperature of is the base of cold pretreatment $\left(4^{\circ} \mathrm{C}\right)$ for 1 or 2 days and heat shock $\left(32.5^{\circ} \mathrm{C}\right)$ for 1 day [15]. Although heat shock treatment plays an important role in cabbage during in vitro microspore embryogenesis [13,14], its mechanism is still unclear. As with other regeneration processes, many species, particularly cabbage, still remain recalcitrant to microspore embryogenesis. Even within a successful specie, there are usually recalcitrant genotypes. Therefore, there is considerable interest in identifying the molecular genetic factors that define and control the microspore embryogenesis process.

Protein is the executor of physiological functions, and following the study of protein structure and function, the mechanistic changes under certain conditions can be more directly stated. Therefore, it is necessary to assess the overall changes in intracellular proteins to reveal the mechanism of plant growth and development changes [16,17]. Proteomics technology has been widely used to explore a variety of plant growth and development in the molecular mechanisms. Protein identification by two-dimensional electrophoresis (2-DE) and mass spectrometry (MS) is one of the most commonly used methods in plant proteomics [18]. Up to now, the combination of 2-DE and MS has enabled us to identify several proteins related to somatic embryogenesis $[19,20,21]$. 2-DE offers the low resolution of proteins and the comigration of proteins in one spot of the gel, in addition, it is difficult to detect proteins with extreme $p$ values and molecular weight [22,23]. In comparative analyses of protein expression, a spectral count, which assesses the total number of assigned MS/MS spectra for peptides from a given protein, is considered to be a label-free quantification method, proteins can be quantified after MS/MS analysis by peptide peak intensity or based on the spectral counting of the peptides identified [24].

Microspore reprogramming not only means the expression of an embryogenic program but also stressrelated cellular responses and inhibition of gametophytic process. A lot of studies concentrated upon casting about for the gene(s) and protein(s) that can effectively induce microspore embryogenesis by using model plant species: rapeseed $[25,26,27]$, tobacco $[28,29]$ and wheat [30]. For example, Pechan et al. identified some heat-shock proteins during the inductive heat treatment of $B$. napus microspores and pollen [11]. By combined transcriptome and proteome analysis, Joosen et al. determined 220 genes and 
32 proteins that are expressed between the 2 and 4 cell and globular/heart stages of embryo development in $B$. napus, with 32 up-regulated proteins being associated with carbohydrate metabolism, redox processes, protein synthesis, glycolysis, and ascorbate metabolism in the microspore-derived embryo (MDE) development [27]. These studies have confirmed that the expression and function of some genes and proteins are related to the development fate of stress microspore. Since microspore embryogenesis is not established in Arabidopsis, there is no large-scale study on microspore embryogenesis using Arabidopsis genome-wide microarray [31]. Molecular systems biology and bioinformatics studies of various organisms have revealed that transcript levels do not always correlate with protein quantity [32,33]. Due to the existence of the transcription levels from the genes to the proteins, posttranslational modifications, such as the role of standards and the regulation of translation, in fact, examining mRNA only identifies the changes that solely take place at the transcriptional level, which cannot be fully representative of the true level of protein expression. Therefore, the data obtained from protein profile analysis is a highly expected supplement that broadens our understanding of the molecular regulation of microspore embryogenesis in vitro pollen cultures of embryogenesis caused by high-temperature treatment.

In this study, a label-free proteomics approach was used to identify and relatively quantify variations in proteins after $32{ }^{\circ} \mathrm{C}$ and $25^{\circ} \mathrm{C}$ treatments for $24 \mathrm{~h}$ in cultured microspores of cabbage accessions Zhonggan 628 (high embryo yield) and 87-534 (low embryo yield). Our analysis focused on the developmental events that take place between the nonembryo and the embryo, identifying proteins that are differentially expressed.

\section{Methods}

\section{Plant materials, treatment and sample collection}

Cabbage (Brassica oleracea var. capitata) accessions Zhonggan 628 (excellent in the embryo yield of microspore culture) and 87-534 (a low yield in microspore-derived embryos) were used in this study, which were cultivated by Institute of Vegetables and Flowers, Chinese Academy of Agricultural Sciences, Beijing, China. The microspore culture of Zhonggan 628 and 87-534 was undertaken from mid-March to early May at the experimental greenhouse of Institute of Vegetables and Flowers, Chinese Academy of Agricultural Sciences, Beijing, China. The microspore isolation and culture procedures were performed as previously described by Lv et al. [7]. Buds with a length of 3-3.5 mm were selected after sterilization, isolation, and finally cultivation. Briefly, NLN-13 was used as the liquid microspore culture media for cabbage [7]. The microspores were incubated in the dark at $32{ }^{\circ} \mathrm{C}$ for $24 \mathrm{~h}$ and maintained at $25^{\circ} \mathrm{C}$ in the dark. Six Petri dishes of each sample were randomly chosen to determine embryogenesis statistics, repeated three times for this test. Simultaneously, the isolated microspores of Zhonggan 628 and 87-534 were divided into two parts, which were collected after $32{ }^{\circ} \mathrm{C}$ and $25^{\circ} \mathrm{C}$ treatments for $24 \mathrm{~h}$, and each part was repeated three times. These collected samples were immediately frozen in liquid nitrogen and stored at $-80{ }^{\circ} \mathrm{C}$ for subsequent extraction of protein and total RNA. 


\section{Plant sample collection and protein extraction}

Microspores treated at $32{ }^{\circ} \mathrm{C}$ and $25^{\circ} \mathrm{C}$ were collected (repeated three times, respectively) and ground separately in extraction buffer contained in a $-20^{\circ} \mathrm{C}$ precooled mortar and pestle in the presence of a urea extraction buffer containing $150 \mathrm{mM}$ Tris- $\mathrm{HCl}$ (pH 7.6), $8 \mathrm{M}$ urea, 0.5\% SDS, 1.2\% Triton X-100, $20 \mathrm{mM}$ EDTA, 20 mM EGTA, 50 mM NaF, 1\% glycerol 2-phosphate, 1 mM PMSF, 5 mM DTT, 0.5\% phosphatase inhibitor mixture, $5 \mathrm{mM}$ ascorbic acid, and $2 \%$ polyvinylpolypyrrolidone. The ratio of frozen plant powder to urea extraction buffer was 1:3 (w/v). Plant cell debris was removed using centrifugation at a lower speed of relative centrifugal force of $10,000 \times \mathrm{g}$ for $1 \mathrm{~h}$ at $4{ }^{\circ} \mathrm{C}$ followed by a higher speed at a relative centrifugal force of $110,000 \times \mathrm{g}$ for $2 \mathrm{~h}$ at $13^{\circ} \mathrm{C}$. The protein supernatant was mixed with three volumes of a cold acetone: methanol (12:1, v/v) organic mix for urea-methanol protein precipitation. The protein pellet was rinsed with 15 volumes ( $\mathrm{v} / \mathrm{w}$ ) of a cold acetone: methanol: $\mathrm{H}_{2} \mathrm{O}$ mix (12:1:1.4, v/v) to remove residual pigment and urea precipitates. The protein pellet was air-dried and redissolved in one-third the volume of resuspension buffer containing $50 \mathrm{mM}$ Tris- $\mathrm{HCl}$ (pH 6.8), $8 \mathrm{M}$ urea, $5 \mathrm{mM} \mathrm{DTT,1 \%} \mathrm{SDS}$, and 10 mM EDTA, and this was followed by another round of protein precipitation and resuspension. The cycling of protein precipitation and resuspension was repeated twice. The proteins were excised from the preparative tube and mixed with $50 \mathrm{mM} \mathrm{NH}_{4} \mathrm{HCO}_{3}$ to the final concentration $0.5 \mathrm{mg} / \mathrm{mL} .100 \mathrm{mmol} / \mathrm{L}$ DTT (dl-dithiothreotol) diluted $10 \mathrm{x}$ with $250 \mathrm{mmol} / \mathrm{L}$ IAM (iodoacetamide) was to the solution with the final concentration of $10 \mathrm{mmol} / \mathrm{L}$ and mixed at $56^{\circ} \mathrm{C}$ for 60 minutes in darkness. At last, the samples from the previous step were digested with trypsin (The mass ratio of matrix to enzyme is $50: 1$ ) at $37^{\circ} \mathrm{C}$ for $12 \mathrm{~h}$. The supernatant fractions were collected at $-80^{\circ} \mathrm{C}$ without further treatment until MS Analysis [62]. The resulting total cellular protein was measured using a protein DC assay (Bio-Rad, Hercules, CA, USA) and calculated using a standard curve of bovine serum albumin.

\section{LC-MS/MS analysis}

The digested peptide mixtures were pressed into a fused silica capillary column packed with 3- $\mu \mathrm{m}$ Dionex C18 material (Dionex, Sunnyvale, USA). The $15 \mathrm{~cm}$ RP column sections with $100 \AA$ was washed with buffer $\mathrm{A}$ (water and $0.1 \%$ formic acid) and buffer $\mathrm{B}$ (acetonitrile and $0.1 \%$ formic acid). After desalting, a 5-mm, 300- $\mu \mathrm{m}$ C18 capture tip was laid up in an Agilent 1100 quaternary (Agilent Technology Co. Ltd., Santa Clara, CA, USA) high-performance liquid chromatography (HPLC) in a straight line, subsequently, 12-step separation method was used for analysis. Gradient elution is as follows: started at $2 \%$ buffer $B$ up to $40 \%$ buffer B in $45 \mathrm{~min}$, to $80 \%$ B in $13 \mathrm{~min}$, from $80 \%$ B to $2 \%$ B until $2 \mathrm{~min}$. The separated peptides were examined in a micrOTOF-Q II mass spectrometer (Bruker Corporation, Billerica, Massachusetts, USA) with a source temperature of $180^{\circ} \mathrm{C}$. The mass spectrometer was running in automatic mode: survey MS scans set to a value of 20,000 , each survey scan $(50 \sim 2,500)$, five data-dependent tandem mass (MS/MS) scans at $2 \mathrm{~Hz}$ normalized scan speed followed closely behind.

\section{Data processing for proteomics}


The MS data were searched against $B$. oleracea genome (http://plants.ensembl.org/index.html) and were processed using Proteome Discover software (Version 1.3, Thermo Scientific, Waltham, USA). Parameters of Proteome Discover searches were set as follows: carbamidomethylation (C), oxidation (M) and Acetylation (Protein N-term) were set as fixed and variable modifications, respectively; peptide mass tolerance was $15 \mathrm{ppm}$, and fragment mass tolerance was $20 \mathrm{mmu}$; max missed cleavages was 2 . The peptide and protein identification were using a cutoff of $1 \%$ for peptide false discovery rate (FDR), peptides with Z score $<4$ or Delta-Mass $>5 \mathrm{ppm}$ were rejected, in addition, to identify a protein the minimum number of peptides was set to 1 . The default parameters for the Quantitative software Profile Analysis 2.0 software were used throughout the analysis. Protein species with fold-change $\geq 1.5$ and $p$ value $(p F D R) \leq 0.05$ were identified as differentially expressed protein species (DEPs) between the experimental groups.

\section{Bioinformatics analysis}

The biological processes, molecular function and cellular components of DEPs were analyzed by using the Evolutionary Relationships (PANTHER) database v6.1 (www.pantherdb.org), which follows the gene ontology (G0) standards [63]. Moreover, signaling pathway analysis was performed on the Kyoto Encyclopedia of Genes and Genome (KEGG) database (http://www.Genome.jp/kegg) for biological interpretation of systemic functions [64]. Protein-protein interactions were obtained from the Search Tool for the Retrieval of Interacting Genes/Proteins (STRING) database (http://string-db.org) containing known and predicted physical and functional protein-protein interactions [65].

\section{Total RNA extraction and qRT-PCR analysis}

The transcript levels of genes involved in DEPs were identified using a real-time quantitative polymerase chain reaction (qRT-PCR). To extract the total RNA, isolated pollen was extracted using an RNA Rapid Extraction Kit (TaKaRa, Dalian, Liaoning, China) following the manufacturer's instructions. A Revert Aid First Strand cDNA Synthesis Kit (TaKaRa) was used to reverse transcribe RNA to cDNA. A SYBR Green Super Mix (TaKaRa) in a $10 \mu \mathrm{L}$ total volume reaction system was used on a CFX ConnectTM Real-Time PCR Detection System (Bio-Rad, Hercules, CA, USA). The qRT-PCR reactions were described previously [29]. Actin was used as the internal reference gene in cabbage. The relative expression levels were calculated using the $2^{-\triangle \Delta C t}$ method and plotted [66], the test repeated three times. The cDNA was amplified using specific primers (Supplementary Table S4).

\section{Results}

Microspore collection and culture

We attempted to collect only late uninucleate microspores as the initial materials for in vitro heat treatment and culture by bud selection. A highly embryogenic cultivar Zhonggan 628 and a low yield cultivar in microspore-derived embryos 87-534 were chosen for the analysis. Treatments of $32{ }^{\circ} \mathrm{C}$ and 25 ${ }^{\circ} \mathrm{C}$ on the isolated microspores for $24 \mathrm{~h}$ were adopted in our experiments. The results showed that after 
two to three weeks, embryoids were produced from the isolated microspore, and the difference in the embryo rates between the $32{ }^{\circ} \mathrm{C}$ and $25^{\circ} \mathrm{C}$ treatments in Zhonggan 628 are significant. In Zhonggan 628 , the average number of embryos per bud is as high as 19.7 after $32^{\circ} \mathrm{C}$ treatment, while the average number of embryos per bud is 0 without $32{ }^{\circ} \mathrm{C}$ treatment, in $87-534$, there was no embryo at both $32{ }^{\circ} \mathrm{C}$ and $25^{\circ} \mathrm{C}$. (Fig. 1). We found that in vitro $32^{\circ} \mathrm{C}$ heat treatment can significantly improve the embryo rate.

Identification of differentially expressed proteins in embryogenesis caused by high temperature

To decipher the proteome variations after treatments at $25^{\circ} \mathrm{C}$ and $32{ }^{\circ} \mathrm{C}$ for $24 \mathrm{~h}$ in cultured microspores, a highly embryogenic cultivar Zhonggan 628 (A) and 87-534 (low yield in microspore-derived embryos, B) after treatments at $25^{\circ} \mathrm{C}$ and $32{ }^{\circ} \mathrm{C}$ for $24 \mathrm{~h}$ were chosen as treatment and control group for the proteome comparisons. Using the label-free analysis, a total of 33434 peptides and 5961 protein species were identified (FDR < 0.01) in the 12 samples (Table S1). Principal component analysis showed clear separation between A and B (Fig. 2). Proteins with more than 1.5-fold changes in abundance $(p \leq 0.05)$ between the HS treatment $\left(32{ }^{\circ} \mathrm{C}\right)$ and $\mathrm{CK}\left(25^{\circ} \mathrm{C}\right)$ were selected as differentially expressed. A total of 363 showed expression differentials in mass spectrometry were identified from Zhonggan $628(\mathrm{~A}), 25^{\circ} \mathrm{C}$ vs $32{ }^{\circ} \mathrm{C}$, among the 363 proteins, 115 were upregulated and 248 were downregulated (Table S1). In 87-534, $25^{\circ} \mathrm{C}$ vs $32{ }^{\circ} \mathrm{C}$, a total of 282 showed expression differentials in mass spectrometry were identified, among the 282 proteins, 162 were upregulated and 120 were downregulated (Table S1). We found that $\mathrm{Y} 1\left(\mathrm{~A} 25^{\circ} \mathrm{C}\right.$ vs $\left.32^{\circ} \mathrm{C}\right), \mathrm{Y} 2\left(\mathrm{~B} 25^{\circ} \mathrm{C}\right.$ vs $\left.32^{\circ} \mathrm{C}\right)$, and $\mathrm{Y} 3\left(\mathrm{~A} 32^{\circ} \mathrm{C}\right.$ vs $\left.\mathrm{B} 32^{\circ} \mathrm{C}\right)$ have 37 proteins in common, there were 210,166 and 357 proteins that could only be detected in $Y 1, Y 2$, and $Y 3$, respectively, in contrast, there were 97 proteins in only $\mathrm{Y} 1$ and $\mathrm{Y} 3,60$ proteins in only $\mathrm{Y} 2$ and $\mathrm{Y} 3$, and 19 proteins in only $\mathrm{Y} 1$ and $\mathrm{Y} 2$ (Fig. 3). We can speculate that those 97 proteins specially identified only in Zhonggan 628 after $32{ }^{\circ} \mathrm{C}$ heat-shock treatment were the proteins that will require more attention.

GO function classification of differentially expressed proteins

To further understand the function of the differentially expressed proteins, 97 key DEPs were searched as described in the materials and methods to obtain their function information. Using GO functional annotation, differentially expressed proteins could be divided into three categories: cellular component, biological process and molecular function (Fig. 4, Table S2). Molecular function and biological process, with 5 and $14 \mathrm{GO}$ terms, respectively; 11 were assigned to cellular component (Fig. 4). Proteins with roles as the cellular component focused on cell and cell part, proteins related to molecular function were primarily the binding protein and catalytic protease, and the proteins related to biological process were primarily involved in cellular process and metabolic process.

KEGG pathway analysis of differentially expressed proteins

According to KEGG analysis with $p \leq 0.05,24$ DEPs were enriched in carbon metabolism, glyoxylate and dicarboxylate metabolism, starch and sucrose metabolism, protein processing in endoplasmic reticulum, glycolysis / gluconeogenesis, carbon fixation in photosynthetic organisms, plant-pathogen interaction 
and cutin, suberine and wax biosynthesis. The results in the KEGG pathway analysis of the differentially expressed proteins after HS responsive embryogenesis (Fig. 5, Table S2) showed that carbon metabolism included nine DEPs, protein processing in the endoplasmic reticulum included eight DEPs, glyoxylate and dicarboxylate metabolism included six DEPs.

The pathway of the different proteins was primarily involved in protein process and carbon metabolism, while some proteins will also be enriched to a different pathway. There were a number of proteins involved in many pathways, such as ribulose bisphosphate carboxylase small chain that were involved in three pathways (carbon metabolism, glyoxylate and dicarboxylate metabolism and carbon fixation in photosynthetic organisms), while participating in more than two pathways of protein as well as sugar isomerase (SIS) family protein and glucose-6-phosphate isomerase.

Interaction of differentially expressed proteins in embryogenesis caused by high temperature.

Plant proteins play interrelated roles together in the context of networks. Detailed analyses of the functional and physical protein interactions of 97 differentially expressed proteins (DEPs, 64 downregulated proteins and 33 upregulated proteins) were validated by constructing an Arabidopsis association model, which was performed to investigate the effects of heat shock treatment on microspore embryogenesis in vitro culture. Although these predicted interaction networks need to be verified, they have provided a narrow pool of protein-protein interactions in embryogenesis caused by high temperature in vitro in cabbage for further investigations.

We applied the STRING database to construct the interaction networks of those 97 DEPs in Arabidopsis. The results showed that 97 DEPs (64 downregulated and 33 upregulated proteins) interacted with 32 and 14 target proteins, respectively (Table S3 and Fig. 6). As expected, the network showed general and complex interactions between the 64 downregulated proteins and 33 upregulated proteins, for example, among those 64 downregulated proteins: hsp21 description (HSP21, corresponding to Bo1g050780.1), putative ankyrin repeat protein RF (TPR10, corresponding to Bo1g151900.1), heat stress transcription factor B-4b-like (HSFA7A, corresponding to Bo2g165560.1), sgt1 homolog B (SGT1, corresponding to Bo3g045210.1), chaperone protein ClpB1 (HSP101, corresponding to Bo6g118620.1) and cell division control protein 48 homolog A (CDC48, corresponding to Bo5g138000.1) closely interact with heat shock $70 \mathrm{kDa}$ protein 5 (HSP70, corresponding to Bo5g021500.1, Bo8g066630.1). In addition, $20 \mathrm{kDa}$ chaperonin (CPN20, corresponding to Bo2g023100.1), malate dehydrogenase ( $\mathrm{mMDH}$, corresponding to Bo6g031300.1), protein SCO1 homolog 1 (HCC, corresponding to Bo5g139630.1) showed very positive interactions with protein disulfide-isomerase (PDIL1-1, corresponding to Bo8g071060.1). For those 33 upregulated proteins: cytochrome P450, family 86 , subfamily C (CYP86C2, corresponding to Bo9g076040.1), non-specific lipid-transfer protein (LTP12, corresponding to Bo1g059070.1), polygalacturonase QRT3 (QRT3, corresponding to Bo1g022160.1) and AT1G06260 (corresponding to Bo1g055000.1) closely interacted with AT1G20120 (corresponding to Bo5g029180.1, Bo7g061770.1, and Bo7g061790.1). 
Niehl et al. found that CDC48 function as a cellular factor to regulate the movement of protein accumulation patterns in plant cells, suggesting a general role of CDC48 in endoplasmic reticulum membrane maintenance upon ER stress (ER) [34]. The most commonly described role of mitochondrial malate dehydrogenase is its catalysis of the interconversion of malate and oxaloacetate in the tricarboxylic acid cycle [35]. The roles of mMDH in Arabidopsis seed development and germination were investigated in $\mathrm{mMDH} 1$ and $\mathrm{mMDH} 2$ double knockout plants; a significant proportion of $\mathrm{mMDH} 1 \mathrm{mMDH} 2$ seeds were nonviable and developed only to torpedo-shaped embryos, indicative of arrested seed embryo growth during embryogenesis [36]. Arabidopsis contains two SGT1 isoforms, SGT1a and SGT1b, and a double mutant would lead to lethal embryos in Arabidopsis, suggesting that the SGT1 proteins are essential for plant development; the SGT1 genes are also involved in enhancing the plant responses to various biotic and abiotic stresses [37,38]. The developmental induction of sHSP has been related to the potential for stress-induced microspore embryogenesis, and the ability of late bicellular pollen to respond to embryogenic induction treatment was accompanied by rearrangements of the microtubular cytoskeleton and the nuclear localization of the $70 \mathrm{kDa}$ heat shock proteins $[39,40]$. These major interacting proteins may play an important role in cabbage embryogenesis.

Correlation of protein fold changes with transcripts.

The protein data and mRNA expression were correlated to further investigate protein relative abundance profiles of embryogenesis caused by high temperature treatment. The mRNA expression levels were obtained using the qRT-PCR analysis of the corresponding nine genes (Those are more nodes in the interaction network). Of the selected proteins, four of the genes showed similar change trends as the result of being label-free. As shown in Fig.7, we chose heat shock $70 \mathrm{kDa}$ protein 5 (Bo5g021500, Bo8g066630), one of the most abundant proteins isolated from the microspore at $32{ }^{\circ} \mathrm{C}$, and, as expected, a significant increase was observed in the expression of $H S P 70$ gene in response to high temperature, similar to $H S P 70$, two genes encoding protein SCO1 homolog $1(\mathrm{HCC})$ and heat stress transcription factor B-4b-like (HSF) showed a relative increased in abundance in Zhonggan 628 under high temperature (Fig. 7). Differently, the gene encoding protein HSP21, CPN20, mMDH, sSGT1and CDC48 showed different changes as a result of being label-free. Those genes showed a low correlation between the mRNA and protein abundance profiles, which displayed a discrepancy between label-free proteomics and qRT-PCR that could be due to sensitivity between the two analytical methods. The other possible reason for this discrepancy maybe introduced by protein posttranscriptional, translational, and posttranslational mechanisms or feedback loops between the processes of mRNA translation and protein degradation.

\section{Discussion}

Proteomics is a powerful tool to study the complex biological systems and developmental processes, such as microspore embryogenesis. To obtain further insights into the mechanism of embryogenesis caused by high temperature, we analyzed the quantitative protein data in detail. In this study, a comparative label-free proteomic analysis was performed to investigate the differences in embryogenetic 
ability between $25{ }^{\circ} \mathrm{C}$ and $32{ }^{\circ} \mathrm{C}$ micropores. The biological significance associated with the biochemical functions of proteins that were differentially abundant between the two types of microspores are mainly discussed in the terms of the two primary categories: carbohydrate metabolism and protein synthesis and degradation.

\section{Carbohydrate metabolic process}

A significant breakthrough in our understanding of embryogenesis caused by high temperature resulted from the carbohydrate metabolic process in cabbage. A total of nine proteins involved in carbohydrate metabolic process, and seven proteins in particular were related to the glycolysis/gluconeogenesis, pentose phosphate pathway and tricarboxylic acid cycle, two proteins participated in glyoxylate and dicarboxylate metabolism (Fig.8).

In various plant species, the comparative analysis of non-embryogenic and embryogenic tissues has shown that most proteins are involved in carbohydrate metabolism, such as in Zea mays [41] and Medicago truncatula [42]. Previous studies have indicated that carbohydrate metabolism participates in the interruption of pollen development, and the genes involved in sucrose-starch metabolism have already been described in barley $[43,44]$. The expression of androgenesis development is divided into two stages: transcripts of the 'early' phase is detected from meiosis until the first pollen mitosis, while the 'late' phase accumulates from the first pollen mitosis onwards [45]. In vivo, the repression of the genes involved in starch biosynthesis has been reported to block pollen development [46]. In this study, a similar mechanism, which was involved in carbohydrate metabolism, may contributed to blocking microspore embryogenesis.

Plaxton et al. found that both the MDE transcriptome and proteome datasets were enriched for mRNAs/proteins involved in glycolysis, a process that generated ATP or metabolites for the biosynthesis of storage products [47]. The accumulation of zygotic embryos and MDES storage products in rapeseed occurred during cotyledon development, which was much later than the embryo stages [48]. This suggested that the glycolysis genes/proteins expressed during very early MDEs were activated to supply the energy needed for the rapid growth that occurred during this phase of embryo development, rather than for storage product biosynthesis [8]. The chloroplast glycolysis occurring under the dark mainly generated carbon skeletons, reductants, and ATP for effective metabolism during SE in vitro [49]. Here, glucose-6-phosphate isomerase (GPI) and sugar isomerase (SIS) family protein were involved in glycolysis that expressed highly during $32{ }^{\circ} \mathrm{C}$ dark-cultured microspore in embryogenic materials zhonggan 628 , this is consistent with above-mentioned studies.

The pentose phosphate pathway (PPP) is a metabolic pathway that is parallel to the glycolysis pathway. Glucose-6-phosphate isomerase (GPI), sugar isomerase (SIS) family protein and transaldolase-like (E2) (Fig.8) participate in the PPP and provide both nicotinamide adenine dinucleotide phosphate (NADPH) and pentose, also increase progressively during embryo development. Malate dehydrogenase (MD) and isocitrate dehydrogenase subunit 2 (IDH) are linked to tricarboxylic acid cycle (TCA), the enzymes are involved in malate metabolism seem to be important for the induction stage of SE in cabbage induced by 
$32{ }^{\circ} \mathrm{C}$. Malate dehydrogenase (MD), commonly found in animals, plants, and bacteria, which can catalyze the reversible conversion between malate and oxaloacetate, chloroplast MD can primarily fix carbon dioxide in photosynthesis [50]. IDH catalyzes the oxidative decarboxylation of isocitrate to produce alpha-ketoglutarate (a-ketoglutarate) and $\mathrm{CO}_{2}$, in which this two-step process comprises the oxidation of isocitrate (a secondary alcohol) to oxalosuccinate (a ketone), which is followed by decarboxylation of the carboxyl group beta to the ketone to form alpha-ketoglutarate [51]. Thus, confirming the importance of malate metabolism during microspore embryogenesis.

These results clearly suggested that all these changes may have increased the amounts of NADH and $\mathrm{FADH}_{2}$ produced in the TCA cycle. Thus, more coenzymes entered the respiratory chain, and the formation of ATP was increased. The high energy requirements associated with the rearrangement of metabolism, cellular organization and regulation, and cell divisions explained why proteins related to carbohydrate metabolic was most strongly expressed during early embryogenesis in vitro. The transformation of carbohydrates and the production of metabolic available energy constitute the physiological axis of somatic embryo induction. This suggested that those upregulated proteins during $32^{\circ} \mathrm{C}$ microspores are activated to supply the energy needed for the rapid growth that occurs during embryo development.

Embryogenesis-related differentially expressed proteins in protein synthesis and degradation

Protein biosynthesis is the basis of life and is the link between genetic information storage in DNA and protein. In this study, the protein metabolism was the second most numerous categories of proteins involved in embryogenesis, we represented nine proteins in Ribosome process (Fig. 9). The endoplasmic reticulum was responsible for protein folding in plant cells, and this process was vulnerable to environmental stresses. ER-associated proteins, included glycosyl hydrolases family 31 protein (RSW3), protein disulfide-isomerase (PDI), ERO2 description, probable mediator of RNA polymerase II transcription subunit 37c (MED), HSP21 description, HSP70, and Cell division control protein 48 homolog A (CDC) were identified in our study (Fig. 9).

Chaperones and proteases ensure correct protein folding and prevent the formation of toxic aggregates. Protein disulfide isomerase (PDI) and flavin adenine dinucleotide (FAD)-dependent oxidase ER oxidoreductin 1 (ERO1) formed disulfide bonds, which both have protein oxidation with redox reactions [52]. PDIs are molecular chaperones that contain thioredoxin (TRX) domains and aid in the formation of the proper disulfide bonds during protein folding [53]. In maize, the primary PDI accumulated to high levels in seeds that produced mutant storage proteins that trigger the induction of the ER stress response [54]. The oxidation and isomerization of disulfide bonds is necessary for the growth of all organisms. In yeast, the oxidative folding of the secretory pathway proteins was catalyzed by the protein disulfide isomerase (PDI), which required ERO1p (endoplasmic reticulum oxidoreductin) for its own oxidation [55].

Misfolded ER proteins were degraded by some HSPs (Fig. 9), because HSPs are not only the molecular chaperones but also the essential components contributing to protein folding, assembly, translocation 
and optimal degradation [56]. HSP70 in the cytosolic heat shock protein family accumulated rapidly to regulate normal growth and development under various stresses [57]. In addition, members of the heat shock protein (HSP) family have been reported to be highly expressed during plant embryogenesis in vitro culture by heat and starvation. Cordewener et al. studied the embryonic development of $B$. napus and revealed that heat shock at $32{ }^{\circ} \mathrm{C}$ for $8 \mathrm{~h}$ was associated with a few de novo synthetic $70 \mathrm{kDa}$ HSPs: HSP68 and HSP70 [58]. The relationship between heat shock treatment and embryogenesis was also studied in B. napus. HSP70 and HSP90 located in the nucleus and cytoplasm were found to be rapidly induced, and the HSP70 protein was upregulated by heat shock stimulation during the process of microspore embryogenesis in B. napus [59]. During transient stress, the aggregation of unfolding proteins is prevented by the protein-protein interactions with the small heat shock protein (sHSP) chaperones; the expression of sHSP is increased by stress, and after upregulation they may become among the most abundant cellular proteins [60]. The sHSP, such as HSP18, HSP21, HSP22, HSP23 (Fig. 9), were also increasingly accumulated in $32{ }^{\circ} \mathrm{C}$ microspores. The increased abundance of HSP70 and sHSP in $32{ }^{\circ} \mathrm{C}$ embryogenic cells suggested that the folding of the synthesized proteins or the refolding of the damaged and unstable proteins occur, which may be due to the stress induced by in vitro culture. The expression of these heat shock proteins is consistent with previous studies.

In the isolated microspore cultures of $B$. napus, the activity of protein synthesis increased from 0 to 5 days at $18{ }^{\circ} \mathrm{C}$, soon afterwards, the activity dropped dramatically, in addition, in MDE cultured at $32{ }^{\circ} \mathrm{C}$, the activity of protein synthesis decreased after 2 days [61]. Here, we found an increase in protein synthesis activity was observed at $24 \mathrm{~h}$ in MDE cultures incubated at $32{ }^{\circ} \mathrm{C}$, this change in protein synthesis capacity may reflect the accelerated isolated microspore development that takes place at 32 ${ }^{\circ} \mathrm{C}$.

\section{Conclusions}

In summary, this study provides a descriptive and comprehensive overview of protein expression changes in the early embryogenesis of $32{ }^{\circ} \mathrm{C}$ induced in cabbage. 97 DEPs specially identified only in Zhonggan 628 after heat-shock treatment were the key proteins that maybe related to heat shock-induced embryogenesis in vitro culture. The key DEPs were enriched in carbohydrate metabolism, protein synthesis and degradation. This work might help to reveal the key proteins of early embryogenesis induced by $32{ }^{\circ} \mathrm{C}$ heat shock treatment in vitro culture of cabbage.

\section{Abbreviations}

DEPs: Differentially expressed proteins; DH: Doubled haploid; 2-DE: Two-dimensional electrophoresis; MS: Mass spectrometry; MDE: Microspore-derived embryo; FDR: False discovery rate; GO: Gene ontology; KEGG: Kyoto Encyclopedia of Genes and Genomes; qRT-PCR: Quantitative real-time polymerase chain reaction; ER: endoplasmic reticulum; sHSP: Small heat shock proteins; TCA: Tricarboxylic acid cycle.

\section{Declarations}




\section{Ethics approval and consent to participate}

Not applicable

\section{Consent for publication}

Not applicable.

\section{Availability of data and materials}

Data of this study have been included in the article or as supplementary material.

\section{Competing interests}

The authors declare that they have no competing interests.

\section{Funding}

This work was financially supported by grants from the National Key Research and Development Program of China (2017YFD0101804), the Science and Technology Innovation Program of the Chinese Academy of Agricultural Sciences (CAAS-ASTIP-IVFCAAS), and the earmarked fund for the Modern AgroIndustry Technology Research System of China (CARS-23).

\section{Authors' contributions}

HNS collected the public dataset, perform bioinformatics analysis and also drafted the manuscript. GC and $\mathrm{XL}$ contributed to bioinformatics analysis and the making of all the figures and tables. HHL and ZYF conceived this study and reviewed the manuscript. LMY, YYZ, YW and MZ reviewed the manuscript. All of the authors read and approved the final manuscript.

\section{Acknowledgements}

The work reported here was performed in the Key Laboratory of Biology and Genetic Improvement of Horticultural Crops, Ministry of Agriculture, Beijing 100081, China.

\section{Author details}

${ }^{1}$ Horticulture and Landscape College, Hunan Agricultural University, Changsha 410128, Hunan, China

${ }^{2}$ Institute of Vegetables and Flowers, Chinese Academy of Agricultural Sciences, Key Laboratory of Biology and Genetic Improvement of Horticultural Crops, Ministry of Agriculture, Beijing 100081, China

\section{Availability of data and materials}

\section{References}


1. Ji JL, Yang LM, Fang ZY, Zhuang M, Zhang YY, Lv HH, Liu YM and Li ZS. Complementary transcriptome and proteome profiling in cabbage buds of a recessive male sterile mutant provides new insights into male reproductive development. J Proteomics. 2018;179(15):80-

2. Su HN, Yang LM, Fang ZY, Zhuang M, Zhang YY and Lv HH. Studies on optimization of cabbage isolated microspore culture conditions and generation of embryoids from high-generation inbred lines. China Vegetables. 2018;4:30- (in Chinese)

3. Abercrombie J, Farnham M, Rushing J. Genetic combining ability of glucoraphanin level and other horticultural traits of broccoli. Euphytica. 2005;143(1):145-

4. Ferrie A, Caswell K. Isolated microspore culture techniques and recent progress for haploid and doubled haploid plant production. Plant Cell Tiss Org. 2011;104(3):301-

5. Germana M. Anther culture for haploid and doubled haploid production. Plant Cell Tiss Org. 2011;104(3):283-

6. Ahmadi B, Shariatpanahi M, Ojaghkandi M, Heydari A. Improve microspore embryogenesis induction and plantlet regeneration using putrescine, cefotaxime and vancomycin in Brassica napus Plant Cell Tiss Org. 2014;118(3):497-505.

7. Lv HH, Wang QB, Yang LM, Fang ZY, Zhuang M, Zhang YY, Sun PT. Breeding of cabbage (Brassica oleracea capitata) with fusarium wilt resistance based on microspore culture and marker-assisted selection. Euphytica. 2014;200:465-473.

8. Hosp J, Maraschin SF, Touraev A, Boutilier K. Functional genomics of microspore embryogenesis. Euphytica. 2007;158:275-285.

9. Shmykova E, Shumilina T, Suprunova P. Doubled haploid production in Brassica Species. Russian J. Genetics: Applied Research. 2016;6(1):6877.

10. Shumilina N, Shmykova LL, Bondareva TT. Effect of genotype and medium culture content on microspore-derived embryo formation in Chinese cabbage (Brassica rapa Chinensis) cv. Lastochka. Biol Bull. 2015;42(4):302-309.

11. Pechan P, Bartels D, Brown D, Schell J. Messenger-RNA and protein changes associated with induction of Brassica microspore embryogenesis. Planta. 1991;184(2):161-165.

12. Custers J, Cordewener J, Nöllen Y, Dons H, Campagne M. Temperature controls both gametophytic and sporophytic development in microspore cultures of Brassica napus. Plant Cell Rep. 1994; 13(5):267-271.

13. Yuan SX, Sun Y, Liu YM, Fang ZY, Zhuang M, Zhang YY. Effects of $p H$, MES, arabinogalactan-proteins on microspore cultures in white cabbage. Plant Cell Tiss Org. 2012;110(1):69-76.

14. Takahata Y, Keller WA. High frequency embryogenesis and plant regeneration in isolated microspore culture of Brassica oleracea Plant Science. 1991;74(2):235-242.

15. Yuan SX, Liu YM, Fang ZY, Zhuang M, Zhang YY. Effect of combined cold pretreatment and heat shock on microspore cultures in broccoli. Plant Breeding. 2011;130(1):80-85. 
16. Balbuena T, Silveira V, Junqueira M, Dias L, Catarina C, Shevchenko A. Changes in the 2-DE protein profile during zygotic embryogenesis in the Brazilian Pine (Araucaria angustifolia). J Proteomics. 2009;72(3):337-352.

17. Rode $\mathrm{C}$, Lindhorst $\mathrm{K}$, Braun $\mathrm{H}$, Winkelmann T. From callus to embryo-a proteomic view on the development and maturation of somatic embryos in Cyclamen persicum. Planta. 2012;235(5):9951011.

18. Balbuena T, Jo L, Pieruzzi F. Differential proteome analysis of mature and germinated embryos of Araucaria angustifolia. Phytochemistry. 2001;72(4):302-311.

19. Almeida A, Parreira J, Santos R, Duque A, Francisco R, Tomé D, Ricardo C, Coelho A, Fevereiro P. A proteomics study of the induction of somatic embryogenesis in Medicago truncatula using 2DE and MALDI-TOF/TOF. Physiol Plant. 2012;146(2):236-249.

20. Correia S, Vinhas R, Manadas B, Lourenço A, Veríssimo P, Canhoto J. Comparative proteomic analysis of auxin-induced embryogenic and non-embryogenic tissues of the solanaceous tree Cyphomandra betacea (Tamarillo). J Proteome Res. 2012;11(3):1666-1675.

21. Sharifi G, Ebrahimzadeh H, Ghareyazie B, Gharechahi J, Vatankhah E. Identification of differentially accumulated proteins associated with embryogenic and non-embryogenic calli in saffron (Crocus sativus). Proteome Sci. 2012;10(1):3.

22. Patel V, Thalassinos K, Slade S, Connolly J, Crombie A, Murrell J, Scrivens J. A comparison of labeling and label-free mass spectrometry-based proteomics approaches. J Proteome Res. 2009; 8(7):3752-3759.

23. Zhu W, Smith J, Huang C. Mass spectrometry-based label-free quantitative proteomics. Biomed Res Int. 2010;1:840518.

24. Lee J, Koh H. A label-free quantitative shotgun proteomics analysis of rice grain development. Proteome Sci. 2011;9(1):61.

25. Soriano M, Li H, Boutilier K. Microspore embryogenesis: establishment of embryo identity and pattern in culture. Plant Reprod. 2013;26(3):181-196.

26. Boutilier K, Offringa R, Sharma V, Kieft H, Ouellet T, Zhang L, Hattori J, Campagne V. Ectopic expression of $B A B Y B O O M$ triggers a conversion from vegetative to embryonic growth. Plant Cell. 2002;14(8):1737-1749.

27. Joosen R, Cordewener J, Supena E, Vorst O, Lammers M, Maliepaard C, Zeilmaker T, Miki B, America T, Custers J, Boutilier K. Combined transcriptome and proteome analysis identifies pathways and markers associated with the establishment of rapeseed microspore-derived embryo development. Plant Physiol. 2007;144(1):155-172.

28. Zarsky V, Garrido D, Rihova L, Tupy J, Vicente O, Heberle-Bors E. Depression of the cell cycle by starvation is involved in the induction of tobacco pollen embryogenesis. Sex Plant Reprod. 1992;5:189-194.

29. Touraev A, Ilham A, Vicente O, Heberle-Bors E. Stress induced microspore embryogenesis from tobacco microspores: an optimized system for molecular studies. Plant Cell Rep. 1996a;15(8):561- 
565.

30. Indrianto A, Barinova I, Touraev A, Heberle-Bors E. Tracking individual wheat microspores in vitro: identification of embryogenic microspores and body axis formation in the embryo. Planta. 2001;212(2):163-174.

31. Hosp J, Maraschin S, Touraev A, Boutilier K. Functional genomics of microspore embryogenesis. Euphytica. 2007;158(3):275-285.

32. Ghazalpour A, Bennett B, Petyuk V, Orozco L, Hagopian R, Mungrue I, Farber C, Sinsheimer J, Kang H, Furlotte $\mathrm{N}$, Park $\mathrm{C}$, Brewer $\mathrm{H}$. Comparative analysis of proteome and transcriptome variation in mouse. PLoS Genet. 2011;7(6):1001393.

33. Baerenfaller K, Massonnet C, Walsh S, Baginsky S, Buhlmann P, Hennig L, Russenberger D. Systemsbased analysis of Arabidopsis leaf growth reveals adaptation to water deficit. Mol Syst Biol. 2012;8:606.

34. Niehl A, Amari K, Gereige D, Brandner K, Mély Y, Heinlein M. Control of tobacco mosaic virus movement protein fate by cell-division-cycle protein48. Plant Signaling \& Behaviorlant Physiol. 2012;160(4):2093-2108.

35. Pernilla L, Olivier K, Hans S, Per G, Thomas M. Reduced mitochondrial malate dehydrogenase activity has a strong effect on photorespiratory metabolism as revealed by $13 \mathrm{C}$ labelling. J Experimental Bot. 2016;67(10):3123-3135.

36. Sew YW, StröHer E, Fenske R, Millar AH. Loss of mitochondrial malate dehydrogenase activity alters seed metabolism impairing seed maturation and post-germination growth in Arabidopsis. Plant Physiol. 2016;171(2):849-863.

37. Yan J, Zhang Y, Ding Y. Binding mechanism between Hsp90 and Sgt1 explored by homology modeling and molecular dynamics simulations in rice. J Mol Model. 2012;18(10):4665-4673.

38. Shanmugam A, Thamilarasan S, Park J, Jung M, Nou I. Characterization and abiotic stressresponsive expression analysis of Sgt1 genes in Brassica oleracea. Genome. 2016;59:243-251.

39. Volkovlrina A, PanchukFritz I, Schöff F. Small heat shock proteins are differentially regulated during pollen development and following heat stress in tobacco. Plant Molecular Biol. 2005;57(4):487-502.

40. Binarova P, Hause G, Cenklová V, Cordewener J, Campagne M. A short severe heat shock is required to induce embryogenesis in late bicellular pollen of Brassica napus Sex Plant Reprod. 1997;10(4):200-208.

41. Varhaníková M, Uvackova L, Skultety L, Pretova A, Obert B, Hajduch M. Comparative quantitative proteomic analysis of embryogenic and non-embryogenic calli in maize suggests the role of oxylipins in plant totipotency. J. Proteomics. 2014;104:57-65.

42. Tom D, Almeida A, Parreira J, Santos R, Duque A, Francisco R, Tomé D, Ricardo C, Coelho A, Fevereiro P. A proteomics study of the induction of somatic embryogenesis in Medicago truncatula using 2DE and MALDI-TOF/TOF. Physiol. Plant. 2012;146:236-249.

43. Maraschin S, Priester W, Spaink $H$, Wang M. Androgenic switch: an example of plant embryogenesis from the male gametophyte perspective. J Exp Bot. 2005;56(417):1711-1726. 
44. Maraschin S, Caspers M, Potokina E, Wülfert F, Graner A. DNA array analysis of stress-induced gene expression in barley androgenesis. Physiol Plantarum. 2006;127(4):535-550.

45. Mascarenhas J. Gene activity during pollen development. Annu rev plant Physiol plant Mol biol. 1990;41:317-338.

46. Datta R, Chamusco K, Chourey P. Starch biosynthesis during pollen maturation is associated with altered patterns of gene expression in maize. Plant Physiol. 2002;130(4):1645-1656.

47. Plaxton W. The organization and regulation of plant glycolysis. Annu Rev Plant Physiol Plant Mol Biol. 1996;47:185-214.

48. Taylor D, Weber N, Underhill E, Pomeroy M, Keller W, Scowcroft W, Wilen R, Moloney M, Holbrook L. Storage-protein regulation and lipid accumulation in microspore embryos of Brassica napus Planta.1990;181:18-26.

49. Flügge U, Häusler R, Ludewig F, Gierth $M$. The role of transporters in supplying energy to plant plastids. J.Exp. Bot. 2011;62:2381-2392.

50. Yudina R. Malate dehydrogenase in plants: Its genetics, structure, localization and use as a marker. Advances in Bioscience \& Biotechnology. 2012;4:370-377.

51. Geng X, Ye J, Yang X, Li S, Zhang L, Song X. Identification of proteins involved in carbohydrate metabolism and energy metabolism pathways and their regulation of cytoplasmic male sterility in wheat. Int J Mol Sci. 2018;19(2):324.

52. Schroder M. Engineering eukaryotic protein factories. Biotechnol Lett. 2008;30:187-196.

53. Houston N, Fan C, Xiang J, Jung R, Boston R. Phylogenetic analyses identify 10 classes of the protein disulfide isomerase family in plants, including single-domain protein disulfide isomeraserelated proteins. Plant Physiol. 2005;137(2):762-778.

54. Li C, Larkins B. Expression of protein disulfide isomerase is elevated in the endosperm of the maize floury-2 mutant. Plant Mol Biol. 1996;30:873-882.

55. Dixon D, Van L, Edwards R, Benham A. Cloning and initial characterization of the Arabidopsis thaliana endoplasmic reticulum oxidoreductins. Antioxid Redox Signa. 2003;5(4):389.

56. Park C, Seo Y. Heat shock proteins: a review of the molecular chaperones for plant immunity. Plant Pathology J. 2015;31(4):323-333.

57. Wang WX, Vinocur B, Shoseyov O, Altm A. Role of plant heat-shock proteins and molecular chaperones in the abiotic stress response. Trends Plant Sci. 2004;9(5):244-252.

58. Jan C, Cordewener G, Gerd H, Eike G. Changes in synthesis and localization of members of the 70$\mathrm{kDa}$ class of heat-shock proteins accompany the induction of embryogenesis in Brassica napus microspores. Planta. 1995;196(4):747-755.

59. Segu-Simarro J, Testillano P, Risuenn M. Hsp70 and Hsp90 change their expression and subcellular localization after microspore embryogenesis induction in Brassica napus J Struct Biol. 2003;142(3):379-391. 
60. Haslbeck M, Franzmann T, Weinfurtner D, Buchner J. Some like it hot: the structure and function of small heat-shock proteins. Nat Struct Mol Biol. 2005;12(10):842-846.

61. Cordewener J, Bergervoet J, Liu CM. Changes in protein synthesis and phosphorylation during microspore embryogenesis in Brassica napus. J Plant Physiol. 2000;156:156-163.

62. Zhu Y, Guo G, Zhang M, Claire Y, Hu Q, Lam H, Cheng H, Xue Y, Li J, Li N. Stable isotope metabolic labeling-based quantitative phosphoproteomic analysis of Arabidopsis mutants reveals ethylene regulated time-dependent phosphoproteins and putative substrates of constitutive triple response 1 kinase. Mol.Cell Proteomics. 2013;12(12):3559-3582.

63. Thomas $\mathrm{P}$, Campbell $\mathrm{M}$, Kejariwal A, Mi H, Karlak B. PANTHER: a library of protein families and subfamilies indexed by function. Genome Res. 2003;13(9):2129-2141.

64. Cho RJ, Campbell M. Transcription, genomes, function. Trends Genet. 2000;16(9):409-415.

65. Jensen L, Kuhn M, Stark M, Chaffron M, Creevey C. String 8-a global view on proteins and their functional interactions in 630 organisms. Nucleic Acids Res. 2009;37:412-416.

66. Schmittgen TD, Livak K J. Analyzing real-time PCR data by the comparative CT method. Nat Protoc. 2008;3(6):1101-1108.

\section{Figures}
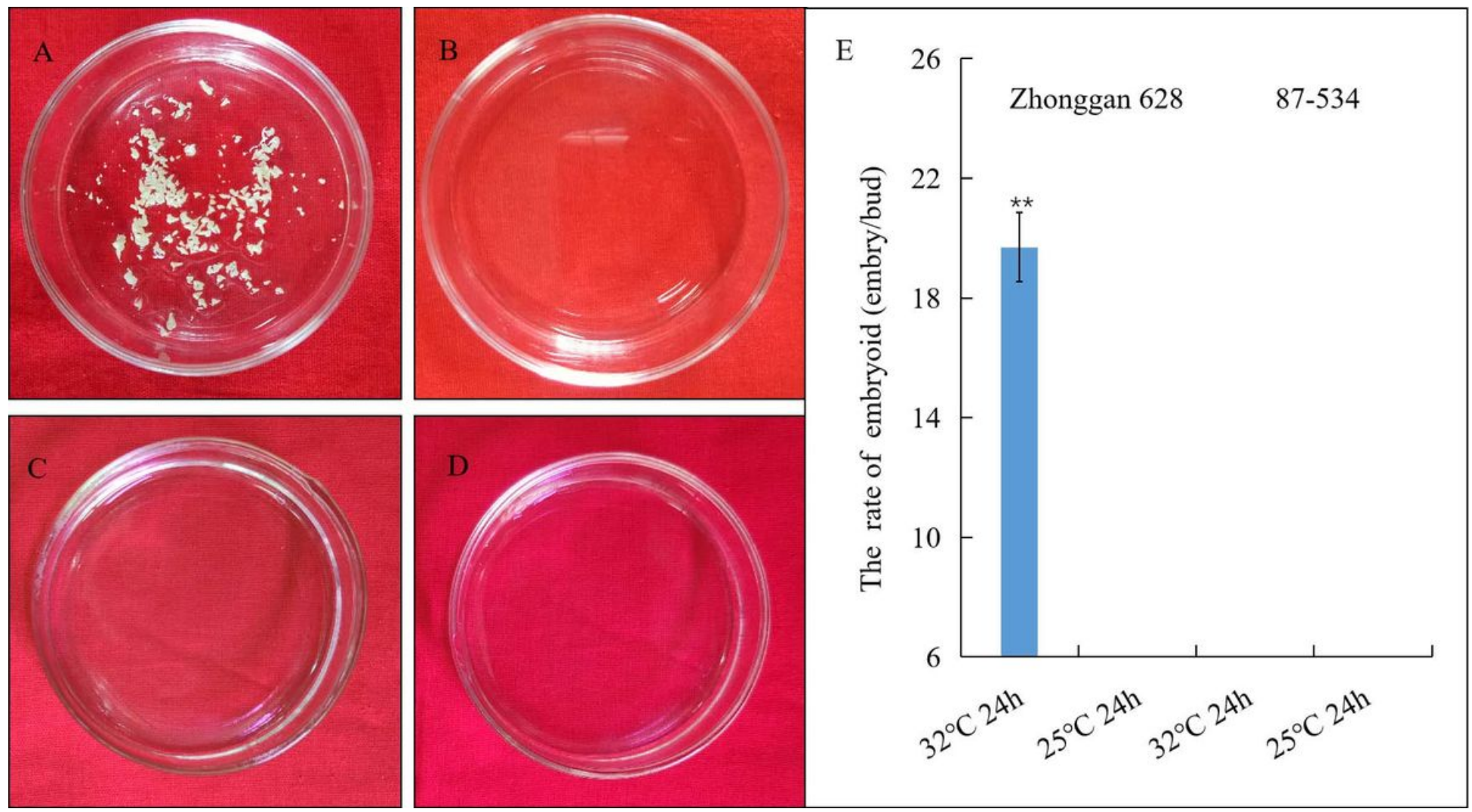

Figure 1 
Microscope observation and statistical analysis of the heat shock treatment of Zhonggan 628 and 87534 microspores in vitro. A: The embryoids after $32{ }^{\circ} \mathrm{C}$ treatment in Zhonggan 628 . B: The embryoids under room temperature of $25^{\circ} \mathrm{C}$ in Zhonggan 628. C: The embryoids after $32{ }^{\circ} \mathrm{C}$ treatment in 87-534. D: The embryoids under room temperature of $25^{\circ} \mathrm{C}$ in $87-534$. E: The rate of embryoids per bud in Zhonggan 628 and $87-534$ between $25^{\circ} \mathrm{C}$ and $32{ }^{\circ} \mathrm{C} 24 \mathrm{~h}$ treatment. Statistical significance of differences between the control $\left(25^{\circ} \mathrm{C}\right)$ and treatment groups $\left(32^{\circ} \mathrm{C}\right)$ were determined by SPSS $17.0(\mathrm{P} \otimes 0.01)$

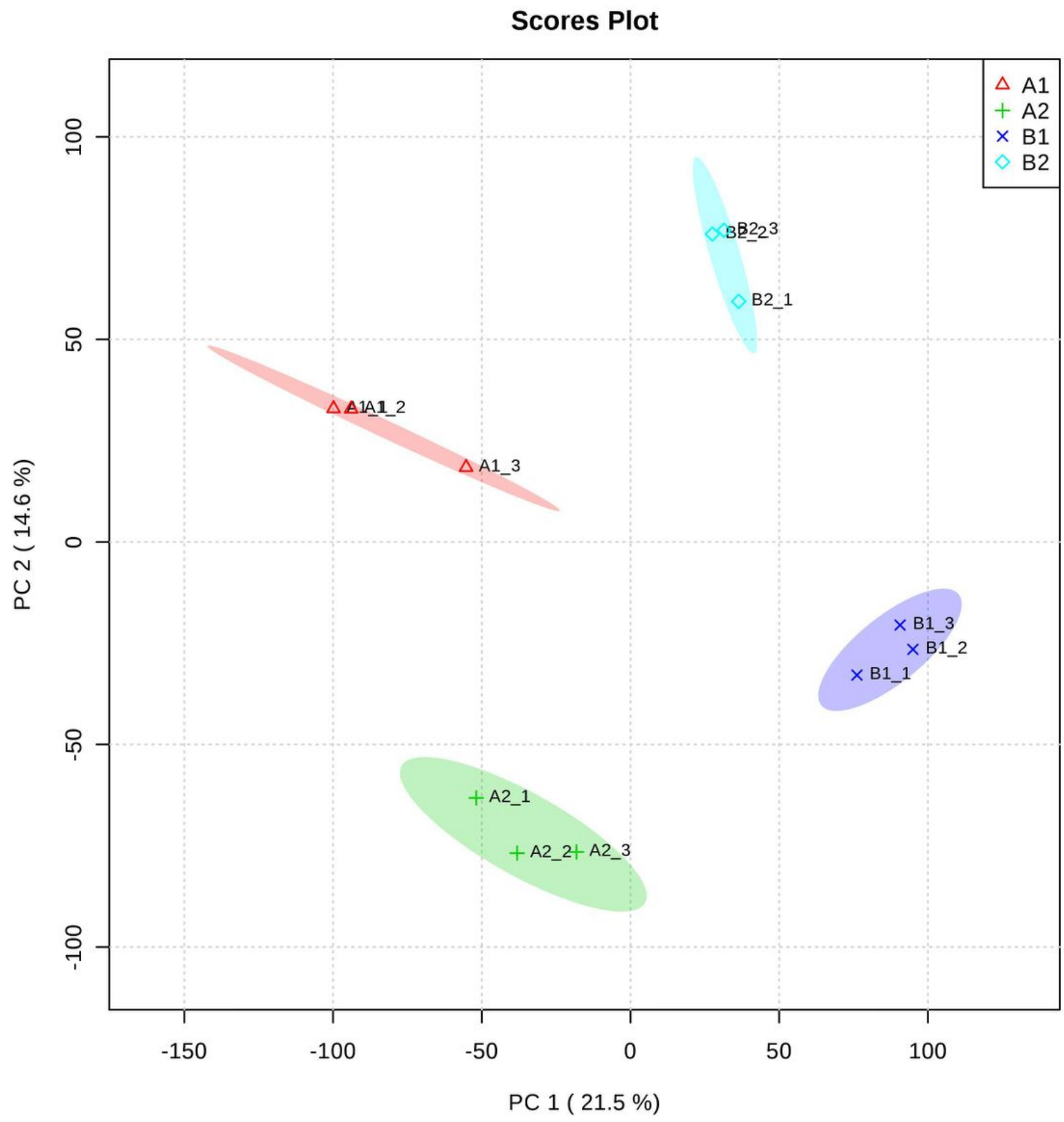

Figure 2 
Principal component analysis at the proteome level. A1: $25^{\circ} \mathrm{C}$ for $24 \mathrm{~h}$ in Zhonggan 628 . A2: $32{ }^{\circ} \mathrm{C}$ for 24 h in Zhonggan 628 . B1: $25^{\circ} \mathrm{C}$ for $24 \mathrm{~h}$ in $87-534$. B2: $32^{\circ} \mathrm{C}$ for $24 \mathrm{~h}$ in $87-534$

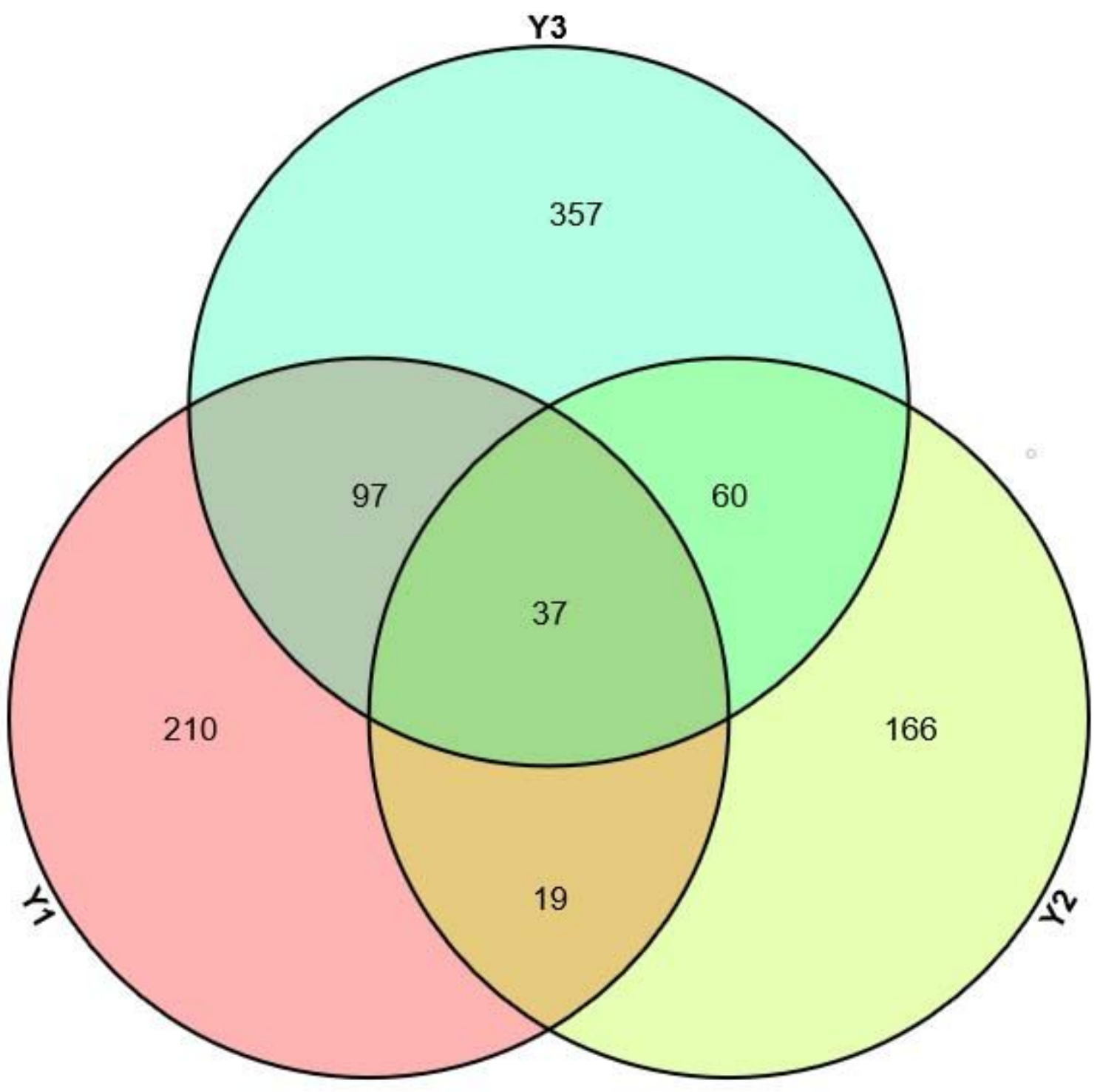

Figure 3

Venn diagrams showing numbers of distinct and common proteins in each of the three groups. $\mathrm{A} 1: 25^{\circ} \mathrm{C}$ for $24 \mathrm{~h}$ in Zhonggan 628 . A2: $32{ }^{\circ} \mathrm{C}$ for $24 \mathrm{~h}$ in Zhonggan 628 . B1: $25^{\circ} \mathrm{C}$ for $24 \mathrm{~h}$ in $87-534$. B2: $32{ }^{\circ} \mathrm{C}$ for $24 \mathrm{~h}$ in 87-534. Y1: A1 vs A2. Y2: B1 vs B2. Y3: A2 vs B2 


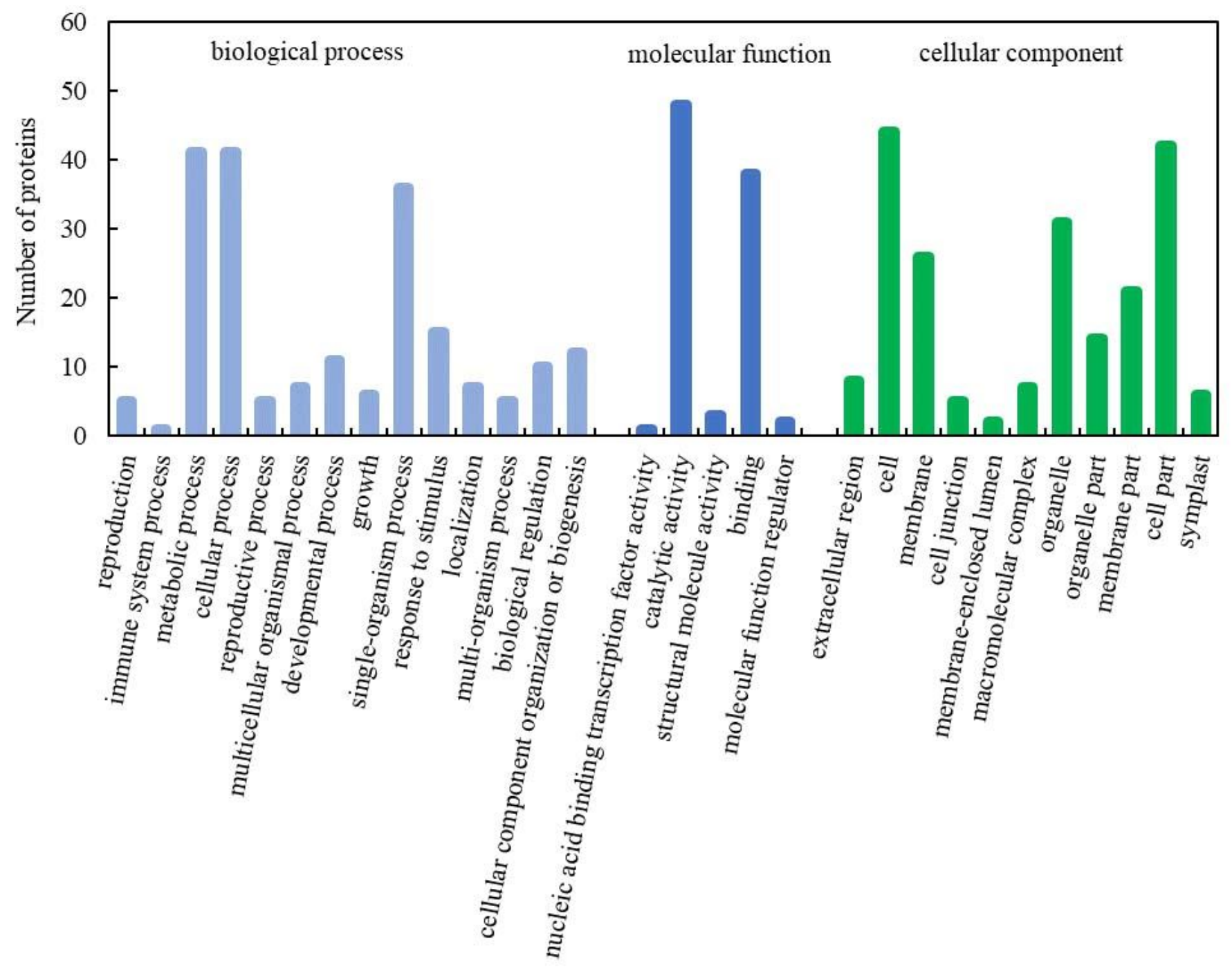

Figure 4

GO function classification of DEPs during embryogenesis caused by high temperature 


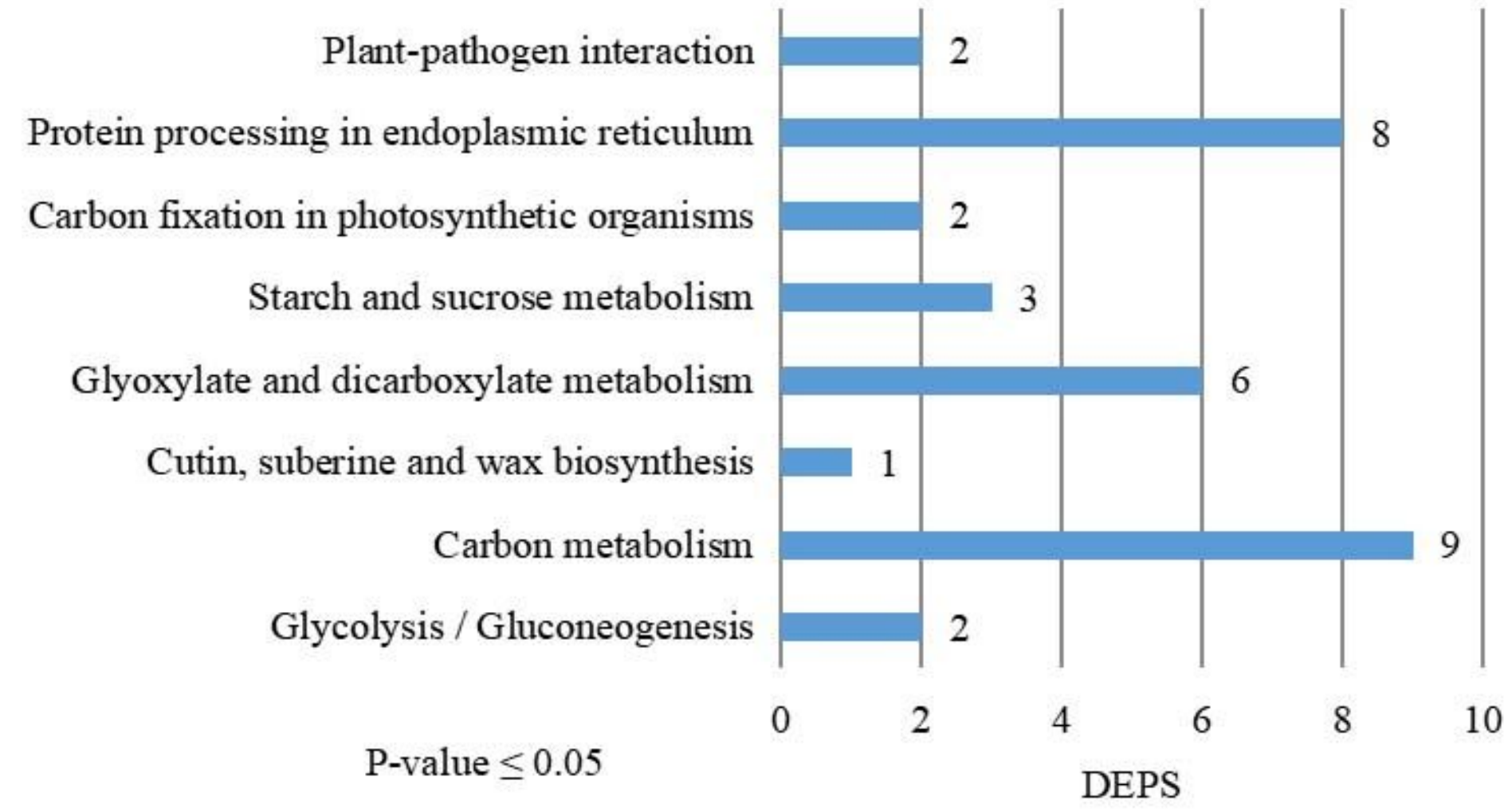

Figure 5

KEGG pathway of DEPs during embryogenesis caused by high temperature 


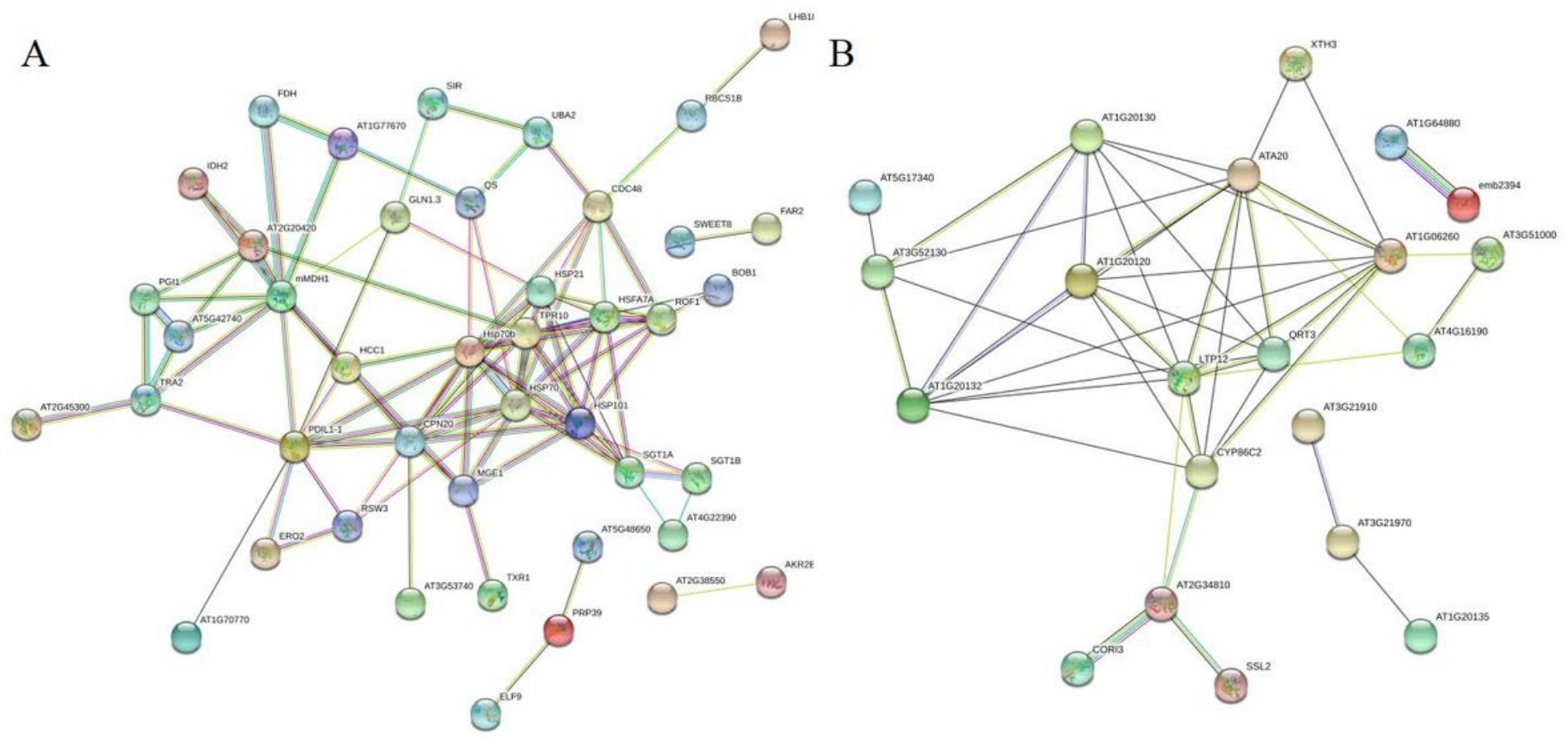

Figure 6

Protein-protein interaction analysis between DEPs. A: The downregulated proteins. B: The upregulated proteins 

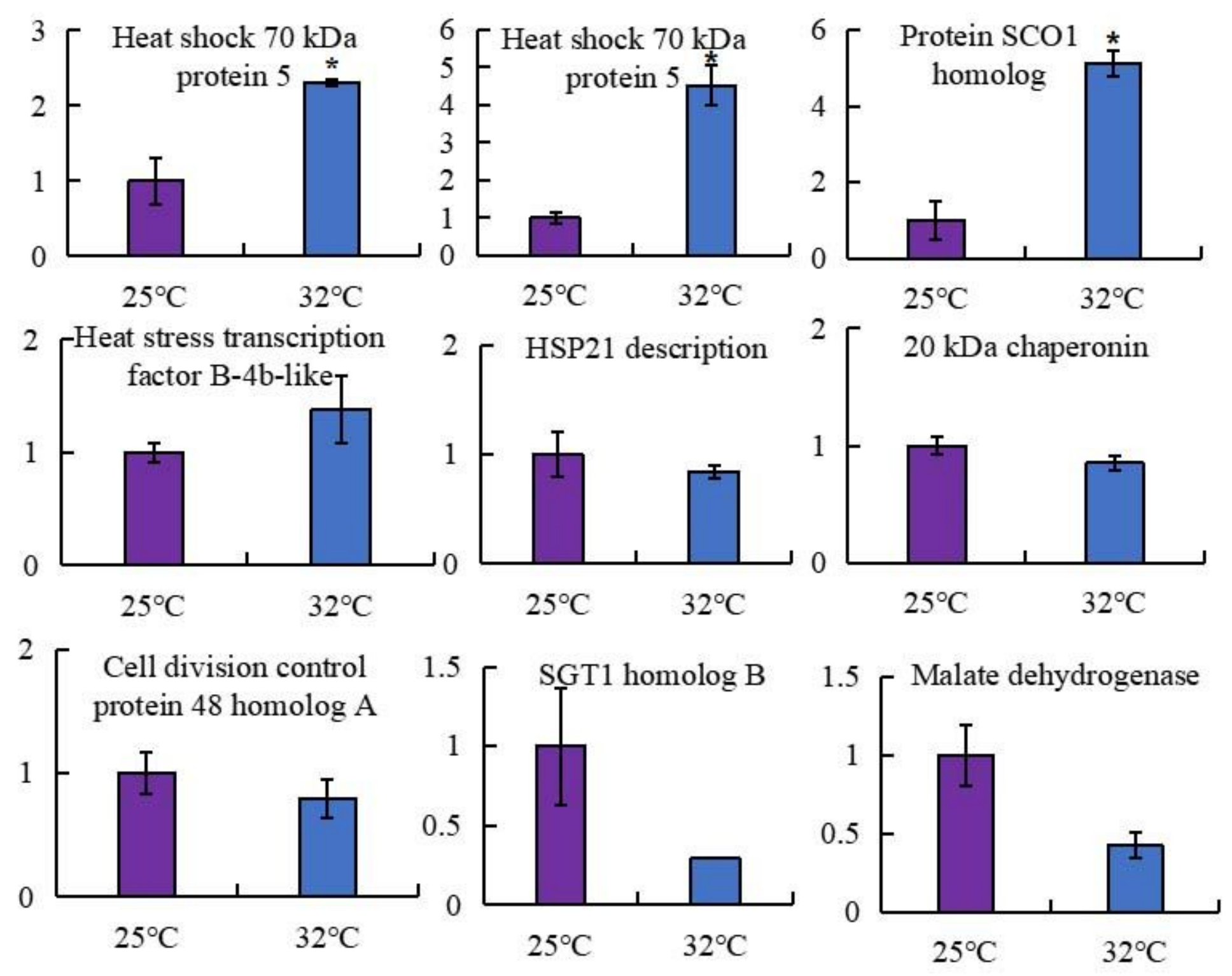

Figure 7

mRNA expression level analysis using a qRT-PCR approach on candidate proteins of embryogenesis caused by high temperature. Statistical significance of differences were determined by SPSS 17.0 (P区 0.05) 


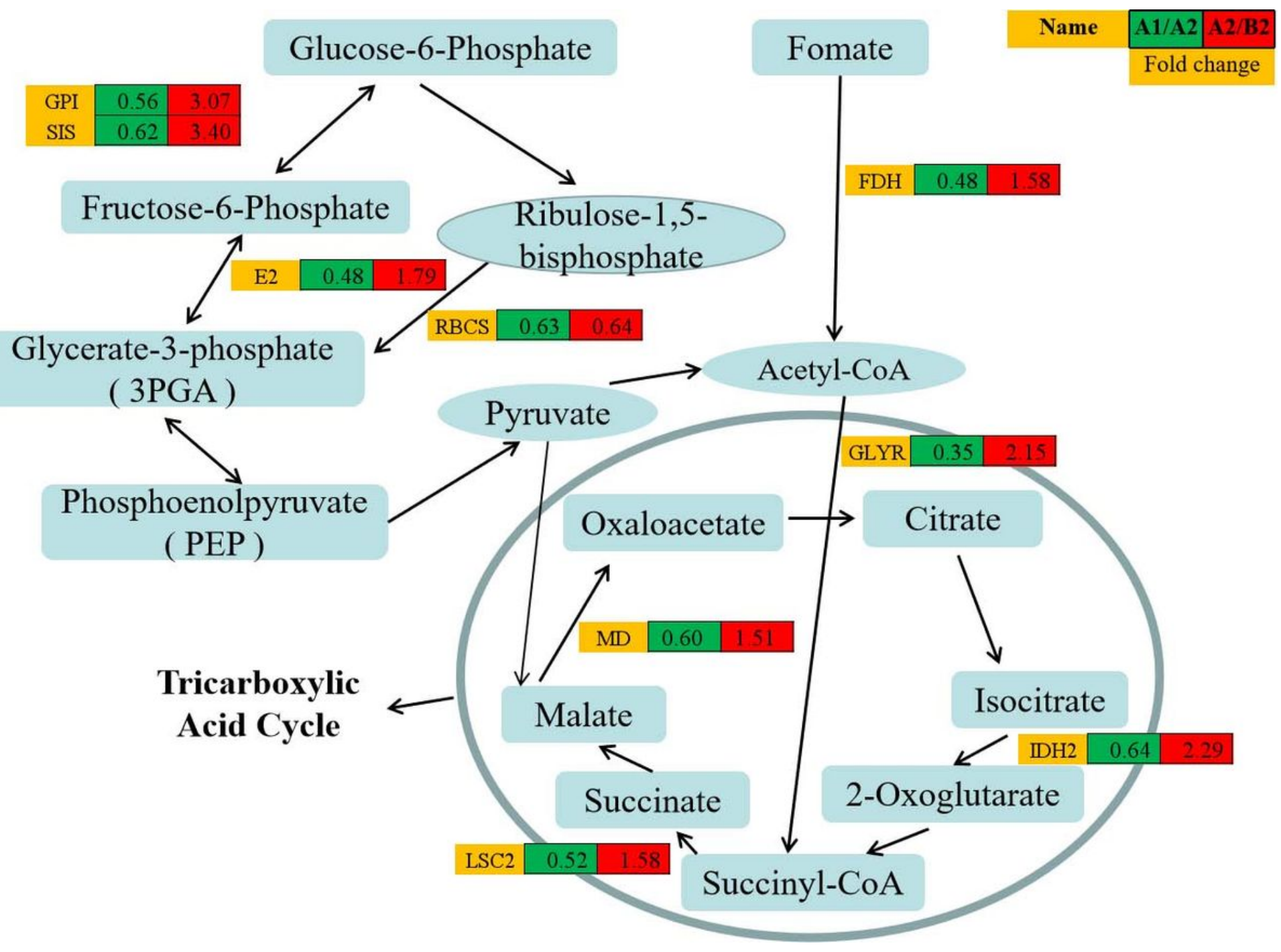

\section{Figure 8}

Abundance patterns of protein species involved in the carbohydrate metabolic. The expression value was $\log 10$ transformed. 


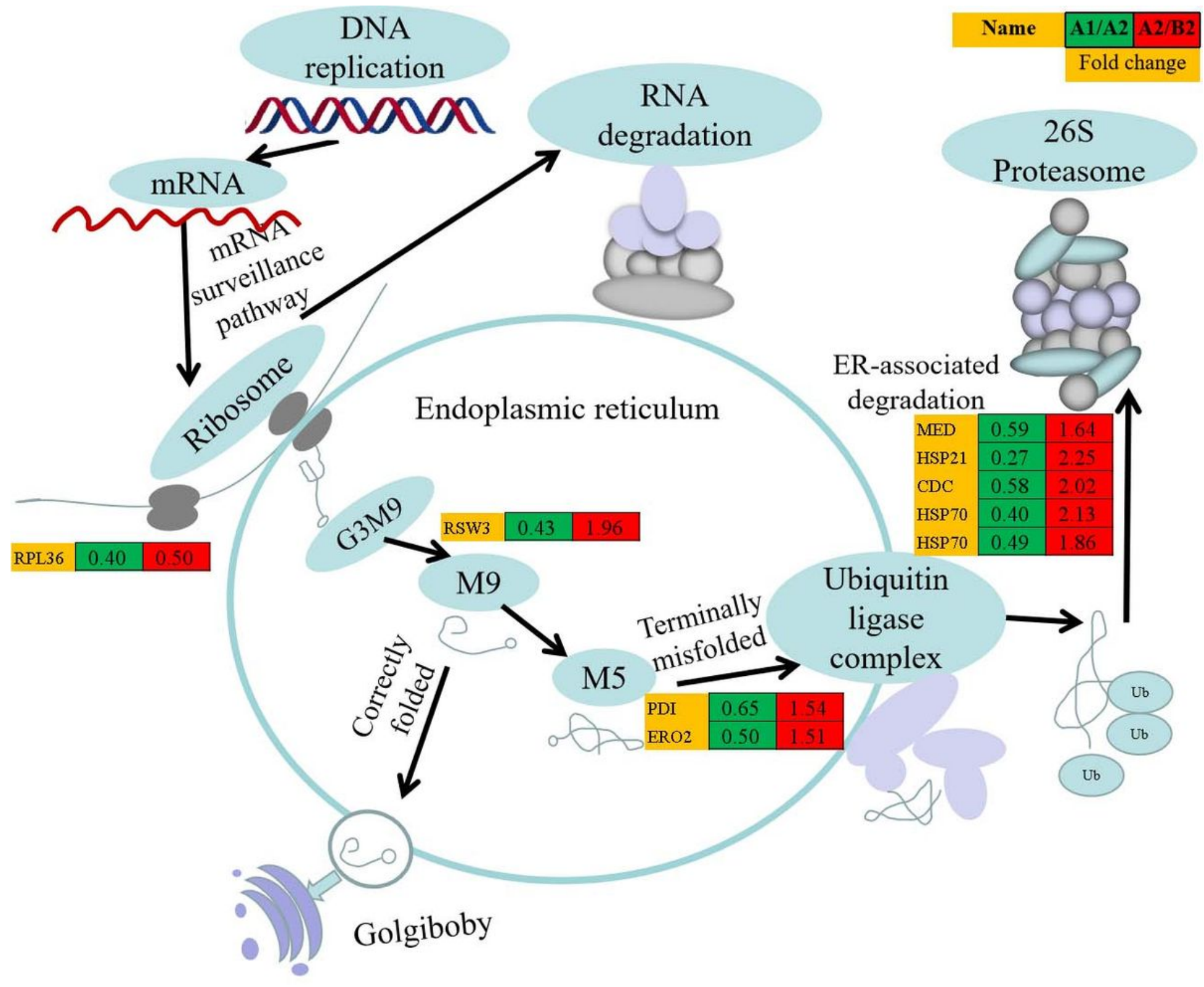

Figure 9

Abundance patterns of protein species involved in protein assembly and degradation. The expression value was $\log 10$ transformed.

\section{Supplementary Files}

This is a list of supplementary files associated with this preprint. Click to download.

- Tables4.xls

- TableS1.xlsx

- TableS2.xlsx

- TableS3.xIsx 